UNTAG Law Review (ULREV)

Volume 2, Issue 2, Nov 2018, PP 118-130

ISSN 2549-4910 (online) \& ISSN 2579-5279 (print)

http://jurnal.untagsmg.ac.id/indeks.php/ulrev/indeks

www.fakhukum.untagsmg.ac.id

\title{
POLICY MODEL FOR THE USE OF ELECTRONIC DOCUMENTS AS \\ A PROOF TOOL IN CRIMINAL ACTION \\ AFTER THE APPLICATION OF LAW NO 19 OF 2016
}

Muhammad Afied Hambali. MH. MH

Students of Law Sciences Doctoral Program in UNISULA

Lecturer at the Law Faculty of the University of Surakarta

Email : Afit.hambali@yahoo.co.id

\begin{abstract}
This paper aims to analyze the policy model of the use of electronic documents as evidence in criminal acts based on Law No. 19 of 2016. The development of information technology has significantly transformed the conventional socialization system into a digital system. This affects the emergence of new legal actions in a community. The form of the new legal action needs to be adjusted and harmonized with existing legislation, such as the use of electronic documents as evidence that will be used as a means of verification in court. Based on the analysis it was revealed that Law No. 19 of 2016 as a legal umbrella for regulating criminal acts in cyberspace is still experiencing many obstacles, therefore it must be harmonized with the relevant criminal law because if it is different then it will cause legal imbalance so that it will increasingly make it difficult for law enforcers to enforce the law.
\end{abstract}

Keywords: model; Policy; electronic documents; evidence.

\section{INTRODUCTION}

At this time information has an important meaning and role in human life, so that the dependence on information is increasing. This triggers changes and developments in information technology with the creation of increasingly sophisticated technological devices and increasingly quality information. Examples such as computers, fax machines, credit card usage, the internet and other things. The internet benefits the community because it provides convenience in carrying out various activities, especially those related to the use of information. One of the most felt benefits is functioning as a medium for sending and receiving information.

The development of cyberspace creates various conveniences for the world of education, commerce, banking and other benefits both economic and social. One of the biggest changes 
due to the use of information technology is the field of socialization and electronic transactions such as the use of mobile banking and internet banking.

Information technology and electronic media are considered as pioneers who integrate all world systems in terms of social, cultural, economic and financial aspects. ${ }^{1}$

Technology has changed a pattern of human life in various fields, so that it directly affects the emergence of new legal actions in a society. The form of the new legal action needs to be adjusted and harmonized with existing legislation, by replacing it if it is no longer appropriate or forming with new provisions.

Besides that, with the development of technology, it can increase violations of legal norms, therefore regulations should also be increased, especially in the case of submission of evidence that will be used as a means of verification in court. ${ }^{2}$ Proof and evidence are very important in order to find a truth and legal certainty.

The enactment of Law No. 19 of 2016 concerning Information and Electronic Transactions (UUITE), is expected to provide useful benefits for law enforcement officials, as well as to prevent unlawful actions that can be done through internet means. However, in reality, since the Law was passed, many people considered the contents of the UUITE limiting internet users to be able to express an opinion and criticize an incident. ${ }^{3}$

Various activities and activities can be carried out by using internet technology, such as e-mail which often creates a legal problem, such as the case of spreading false news about failure to complete interbank transactions through electronic systems conducted by Erick J Ardiansjah. Likewise the case of Prita Mulyasari who complained about the poor service of the OMNI Hospital via e-mail and other cases.

It should be understood that the development of the use of electronic devices in various transactions, especially in socializing, has the advantage of being efficient, fast, easy, but there are disadvantages, namely when faced with evidence problems in court, in other words, the development of technology has a large impact on people's lifestyle positive or negative

\section{Problems}

1. How is the regulation of the use of electronic documents as evidence in criminal acts after Law No. 19 of 2016 applies?

2. What factors inhibit the use of electronic documents as evidence in criminal offenses?

1 Dikdik M Arief dan Elisatris Gultom, Cyber law : Aspek Hukum Tehnologi Informasi, Refika Aditama, Bandung, 2009, hal. 1

2 Munir Fuady, Teori Hukum Pembuktian (Pidana dan Perdata), Citra Aditya Bakti, Bandung, 2001, p .151

3 Enda Nasution, http://blog.kenz.or.id/2006/02/09/difinisi-blog-menurut-orang-indonesia.html 


\section{FOUNDATION OFTHEORY}

\section{Overview of Evidence in Crime}

Proof is a very important thing because as a supporter in finding the true truth, even though there are still defects in it. Verification law is one of the criminal procedural law. This is very closely related to how a judge decides a criminal case on the basis of evidence, and so on. The law of proof is a part of the criminal procedure law that regulates various types of legal evidence, the system adopted in proof, the conditions and procedures for submitting such evidence and the authority of the judge to accept, reject and evaluate evidence. The criteria that can be called proof are: a). shows events that can be received by the five senses, $b$ ). member information about the events that have been received, and c). use logical mind.

Furthermore, relating to evidence is all things that have to do with an act, wherein such evidence can be used as evidence material in order to create a judge's confidence in the truth of a criminal act committed by the defendant. The legal evidence according to KUHAP article 184 paragraph 1 is:

\section{Witness testimony}

According to article 1 point 27 of the Criminal Procedure Code, witness testimony is one of the evidences in a criminal case in the form of a statement from a witness concerning a criminal incident which he heard himself, he saw for himself and experienced by himself by mentioning the reasons for his knowledge. Furthermore, in article 185 paragraph 5 of the Criminal Procedure Code it is stated that either the opinion or fabrication obtained from the results of thought alone is not a witness statement. Article 185 paragraph 1 states that witness testimony does not include information obtained from other people (testomonium de auditu) such as Andi Hamzah's opinion ${ }^{4}$ stating that de auditu's testimony is not evidence, because it is not in accordance with the purpose of criminal procedure law, namely seeking material truth and protection of human rights, where the testimony of a witness who only hears from others is not guaranteed.

Likewise, the opinion of Wiryono Projodikoro in Andi Hamzah stated that judges were prohibited from using evidence from a statement from the de auditu witness, namely about a situation that the witness only heard from other people. This prohibition is good even if it should, but it must be noted that if there are witnesses who explain that they have heard of a situation from another person, such testimony cannot always be put aside. Maybe once a hearing event from someone else can be useful for the preparation of a series of proofs against the defendant. ${ }^{5}$ However, de auditu's testimony also needs to be heard by a hakin, although it

4 Andi Hamzah, Hukum Acara Pidana Indonesia, Sinar Grafika, Edisi ke dua, Jakarta, 2009, p. 264

5 Ibid, p. 266 
does not have value as evidence of testimony of testimony, but it can strengthen the judge's conviction that comes from two other evidences.

\section{Expert information}

According to article 1 point 28 of the Criminal Procedure Code expert testimony is a statement given by a person who has special expertise regarding matters needed to make a suspect or criminal case for the purposes of examination in terms of and according to the manner stipulated in the Act. The information of an expert is different from that of a witness, although both are difficult to distinguish because sometimes an expert is also a witness. Fill in the information of a different witness and expert. The testimony of a witness concerning what the witness experienced himself while the testimony of an expert was about an assessment of things that were already apparent and conclusions regarding these matters. ${ }^{6}$ It is noteworthy that the Criminal Procedure Code distinguishes the testimony of an expert in the court as evidence of "expert testimony" (article 186 of the Criminal Procedure Code) and the statement of an expert in writing outside court proceedings as evidence (article 187 point c KUHAP)

\section{Letter}

According to article 187 of the Criminal Procedure Code the letter as referred to in article 184 paragraph 1 letter $\mathrm{c}$ is made on oath of office or strengthened by oath, are: official reports and other letters in an official form made by the authorized official or made before him, containing information about the incident or the situation heard, seen or experienced by itself is accompanied by clear and explicit reasons regarding the statement.

a. Letters made according to the rules of legislation or letters made by officials regarding matters which are included in matters of governance which are their responsibility and which are intended to prove something or something.

b. A certificate from an expert who contains an opinion based on his expertise regarding something or something that is formally requested and to him

c. Another letter that can only be valid if there is a connection with the contents of another evidentiary tool.

\section{Directions}

Guidance is an act of events, or a situation because the adjustment is good between one and the other and with the crime itself indicates a crime and who is the perpetrator, this is what is stated in article 188 paragraph 1 of the Criminal Procedure Code. An evaluation of the strength of evidence from a guideline in any particular situation is carried out by the judge wisely, after he

$6 \quad$ Ibid,p. 274 
has conducted an examination with full precision and similarity based on his conscience. ${ }^{7}$ Thus the instructions are the same as the observation of the judge as evidence, observations by the judge must be carried out during the trial, what has been experienced or known by the previous judge cannot be used as evidence basis, unless the act or event is known to the public.

5. Defendant's information

According to article 189, paragraph 1 of the Criminal Procedure Code, it determines: "the defendant's statement is what the defendant stated in the court session about the actions committed or he knew himself or experienced himself". In article 189 paragraph 4 of the Criminal Code it has been stated that: "the testimony of the defendant alone is not enough to prove that he has been guilty of the act that was indicted against him, but must be accompanied by other evidence. Information of the defendant as evidence containing or marking about:

a. What the defendant stated, or explained in court.

b. What is explained about the actions of the defendant or about what he knows, naturally from the events being examined.

\section{Sources of Proof}

Furthermore, with regard to sources of evidence, there are several things that can be used as sources of evidence, among others,

1. Law

2. Doctrine or teaching

3. Jurisprudence

It should be noted that when in the practice of proof if it finds difficulties in its application or there is a lack of proof. Therefore to fulfill the needs of the use of doctrine or jurisprudence.

\section{Proof System or Theory}

Proof is very important because it proves as a supporter to seek true truth. Proof is one part of criminal procedural law which is very closely related to how a judge will decide a criminal case on an evidence basis. There are 4 evidentiary theories in criminal law, namely:

1. Theory of proof based on mere judge confidence (Conviction in time)That is, the guilty or not guilty of the accused against the act indicted depends entirely on the judgment of the judge alone. So whether the accused is wrong or whether the defendant is convicted is entirely dependent on the judge's conviction, and the judge's conviction does not have to arise or be based on the available evidence. Even though the evidence is sufficient, but if

7 Ibid, p. 277 
the judge is not sure, the judge may not impose a sentence, on the contrary, although the evidence is not available, but if the judge is convinced, the defendant can be found guilty. As a result of these conditions, in deciding a case the judge becomes very subjective. This system is widely used by countries that use jury justice systems. ${ }^{8}$

2. Theory of proof based on the judge's belief in logical reasons (Conviction In Raison). In this system the belief of the judge still plays an important role in determining whether or not the defendant is wrong, but in this system the belief factor of the judge is "limited". If in the Conviction in Time system, the role of the judge's beliefs is free without limits, but in this system the judge's belief must be supported in the presence of clear reasons. This means that the Judge must base the decision on a defendant based on reason (reasoning). Therefore the decision is also based on reasons that can be accepted by reason. The judge must explain and explain the reasons underlying the conviction of the defendant's fault. This theory is also called Free Evidence because the belief of the judge is free to mention the reasons for his belief.

3. The theory of proof according to the law is positive (positief wattelijke bewijs theori) is a system of positive proof depends on the evidence as mentioned in the law. In short, the law has found out which evidence can be used by the judge, how the judge uses it, the strength of the evidence and how the judge must decide whether or not the case is being tried. So if the evidence is in accordance with the law, the judge must determine that the defendant is guilty even though the judge believes that the defendant is innocent. According to Simons, this system seeks to get rid of all the subjective judgment of judges and bind judges strictly according to strict evidentiary rules, adhered to in Europe at the time of the entry into force of the principle of inquisitoir in criminal proceedings.

However, this theory has no longer been accepted, and this theory was rejected by Wiryono Projodikoro for adoption in Indonesia, according to him how judges can set the truth other than by expressing their beliefs about the truth, and the conviction of honest and experienced judges is increasingly appropriate with public confidence. The goodness of this system is that the judge will try to prove the fault of the defendant without being influenced by his conscience so that it is truly objective because according to the methods and evidence determined by law.

4. Negative verification system according to the law (negatief wattelijke bewijs theori), namely that the judge may only impose a sentence against the defendant if the evidence is limited by law and supported by the judge's belief in the existence of the evidence.

8 Hari Sasangka dan Lily Rosita, , Hukum Pembuktian Dalam Perkara Pidana, Mandar Maju, Bandung, 2003, p. 15 
Indonesia adheres to this negatively proven system of law. In this system there is a dominant element in the form of at least two (2) evidence, while the judge's belief is only a complementary element. The judge in making a decision about whether or not a defendant is bound by evidence determined by law and belief or the judge's conscience.'

Furthermore, regarding the principles in verification in criminal law are as follows:

a. Things that are generally known do not need to be proven (notoire felten)

b. One witness not a witness (unus testis nullus testis)

c. The defendant's testimony is not enough to prove that he is guilty.

\section{DISCUSSION}

\section{Arrangement of electronic evidence before Law No. 19 of 2016}

The use of information technology that is increasingly widespread in the community has led to a variety of modes of crime that exist, while the law enforcement process often becomes ineffective. Because the system and regulation of evidence have not been able to accommodate evidence of information technology products, such as in criminal acts which are categorized as "extra ordinary crime" (criminal acts of terrorism, corruption, money laundering, banking crimes and so on).

Therefore information technology products as electronic evidence can then be accepted as an extension (extensification) of the evidence provided for in article 188 paragraph 2 of the Criminal Procedure Code.

This condition began in the formulation of Law No. 20 of 2001 as a change from Law No. 31 of 1999 concerning the Eradication of Corruption Crime, Law No. 15 of 2002 Jo of Law No. 25 of 2003 concerning Money Laundering, and Perpu No. 1 of 2002 which later promulgated in Law No. 15 of 2003 concerning the Eradication of Crime of Terrorism, which has gradually utilized information technology such as conducting tapping, conducting cell phone cloning, SMS, computer outreach, facsimile, voice recording, CD rooms, and other recording devices acceptable to the court as evidence, especially in terms of finding evidence evidence. ${ }^{10}$

However, in practice judges are not well acquainted with electronic products whose types and forms are very large, therefore it is necessary to hear the statement of one or several witnesses who have expertise in information technology to explain the types of electronic products that can be used as evidence in relation with efforts to expand the area to find evidence evidence in

9 Adnan Paslyadja, Hukum Pembuktian, Pusat Diklat kejaksaan Republik Indonesia, Jakarta, 1997, p.16-22

10 Djoko Sarwoko, Pembuktian Perkara Pidana Setelah Berlakunya UU No 11 Tahun 2008 (Undang-Undang ITE), Tuada Pidana Khusus Mahkamah Agung, 
the case he is handling. ${ }^{11}$

Electronic products that have been translated or read by an expert and used as evidence, in fact the value is the same as the expert's statement, where the expert's information is also a standalone evidence.

But if the expert's information cannot establish a fact and obtain a complete conclusion to realize evidence that can stand alone, it will still be evidence evidence.

Arrangement of electronic evidence after the enactment of Law No. 19 of 2016 concerning ITE

Nowadays, all electronic transactions have been implemented a lot, for example for the purposes of transferring funds, payments, purchases, information and so on. Where through electronic transactions, consumers will get proof of transactions in the form of electronic information or electronic documents / printed results.

Through Law No. 19 of 2016 concerning Information and Electronic Transactions (UUITE), electronic information or electronic documents / printouts are valid legal evidence.

In article 1 point 4 of the UUITE referred to as electronic document, every Electronic Information that is made, forwarded, sent, received or stored in the form of analog, digital, electromanetic, optical or the like can be displayed, and / or heard through a Computer or Electronic System, including but not limited to writing, sound, images, maps, designs, photos or the like, letters, signs, numbers, access codes, symbols or perforations that have meaning or meaning or can be understood by people who are able to understand them. ${ }^{12}$

Whereas in Article 1 number 1 the ITE Law the notion of Electronic Information is one or a set of electronic data, including but not limited to writing, voice, images, maps, designs, photos, electronic data interchange (EDI), electronic mail, telegrams, telex, telecopy or the like, letters, signs, numbers, access codes, processed symbols or perforations that have meaning or can be understood by people who are able to understand them.

In principle, electronic information can be distinguished but cannot be separated from electronic documents. Electronic information is data or collections in various forms while electronic documents are containers or packages of electronic information. ${ }^{13}$

In principle, electronic information can be distinguished but cannot be separated from electronic documents. Electronic information is data or collections in various forms while

11 Johan Wahyudi, Dokumen Elektronik Sebagai Alat Bukti Pada Pembuktian di Pengadilan, Jurnal: Perspektif Volume XVII No 2, Fakultas Hukum Universitas Airlangga,Surabaya, Edisi Mei 2012, p. 123

12 UU No 19 Tahun 2016 tentang Informasi dan Transaksi Elektronik ( ITE)

13 Ibid 
electronic documents are containers or packages of electronic information.

For example, if we talk about music files in the form of mp3, all information or music that comes out of the file is electronic information, while electronic documents from the file are mp3.

Article 5 paragraph 1 of the ITE Law states that there are two types of evidence in the scope of electronic transactions, namely:

- Electronic information and electronic documents

- Print results from electronic information or electronic documents

Furthermore, in Article 5 paragraph 2 of the ITE Law states that electronic information and / or electronic documents and / or printed results as referred to in paragraph 1 constitute an extension of legal evidence in accordance with the applicable Procedural Law in Indonesia.

These two things are important from the provisions concerning the extension of legal evidence and in accordance with the applicable law in Indonesia. Understanding of expansion must be related to article 5 paragraph 1 of the UUITE, the expansion in question is: $:^{14}$

- Extending the number of evidence stipulated in the Criminal Procedure Code, where in the Criminal Procedure Code regulated 5 evidences, then based on article 5 of the ITE Law the evidence in the Criminal Procedure Code is added with one proof instrument namely Electronic Information and Electronic Documents. This is what is called electronic evidence.

- Extending the scope of evidence provided for in the Criminal Procedure Code.

The print out of electronic information or electronic documents is essentially a letter, and the letter of evidence is regulated in the Criminal Procedure Code.

Furthermore, the expansion also meant that Electronic Information and / or Electronic Documents could be used as sources of guidance as possible in the law. ${ }^{15}$

Understanding "in accordance" with the applicable procedural law in Indonesia is intended as the same as the evidence stipulated in the Criminal Procedure Code, which must fulfill both formal and material requirements so that it can be legally declared as evidence. ${ }^{16}$

The formal conditions in question are requirements regarding the formality or form of Electronic Information and / or Electronic Documents, in which Article 5 paragraph 4 of the

14 Djoko Sarwoko, opcit, p.10

$15 \mathrm{Ibid}$, hal 12

16 Johan Wahyudi, opcit 
Law states that electronic information or documents are not documents or letters which according to the law must be in written form.

While the material requirements are regulated in article 5 paragraph 3 of the UUITE, Article 6 of the UUITE, article 15 of the UUITE and article 16 of the UUITE. Where in essence, information and electronic documents that will be used as valid evidence must come from reliable, safe and responsible electronic systems and meet the minimum requirements as follows:

1. Can re-display electronic information and / or electronic documents in full in accordance with the retention period stipulated by legislation;

2. Can protect the availability and accessibility of electronic information in the operation of the electronic system;

3. Can operate in accordance with procedures or instructions in the operation of the electronic system;

4. Equipped with procedures or instructions announced with language, information or symbols that can be understood by the parties concerned with the implementation of the electronic system;

5. Has a continuous mechanism to maintain novelty, clarity, and dependence on procedures or instructions.

Furthermore, it should be noted that those who submit electronic / electronic document information as evidence are making appropriate efforts to ensure that an electronic system has been able to protect the availability, integrity, authenticity, confidentiality and accessibility of said electronic information.

Therefore to fulfill the material requirements in UUITE digital forensics is needed, namely the whole process of retrieving, restoring, storing, checking information or electronic documents contained in electronic systems or storage media based on methods and tools that can be scientifically accounted for for the sake of proof.

Besides that there are several types of documents that cannot be used as valid evidence if they are made in the form of electronic information and / or electronic documents. The documents are as follows:

1. Aletter which according to the law must be written in writing;

2. Letters and documents which according to the law must be made in the form of a notarial deed or deed made by the deed-making official. 


\section{Factors that Inhibit the Use of Electronic Data as Evidence in Crime.}

Amid the rapid development of information technology, including the use of the internet as it is today, it cannot be denied that the existence of the rule of law is a must. Where the rule is a tool for conducting control so that the use of information technology media does not interfere with the conduciveness and security of society but when it is not observant, it is not impossible that the rule is misinterpreted as a form of limitation or restriction of the right of opinion or expression of citizens. Especially in a country that adheres to democracy like Indonesia which is very close to freedom. Even though the freedom in question is not free freely without recognizing boundaries, still such a form of limitation will create its own prejudice for society.

The ITE Law which has been legally enacted since March 25, 2008 is a legal umbrella in the use of information technology in Indonesia, however, this law is considered to limit freedom of expression, issue opinions so that it can hamper creativity in surfing, especially with article 27 Paragraph 1, Article 27 Paragraph 3, Article 28 Paragraph 2 and Article 31 Paragraph 3, these articles are considered to contain the provisions of the Article of Rubber (Haatzai Pasalen), because they are flexible and depend on the interpretation of users of this UUITE. Meanwhile the threat of speech for the three articles is imprisonment for a maximum of 6 (six) years and / or a fine of at most 1 (one) billion, besides that in the context of criminal law, the three offenses contained in these articles are categorized as formal offenses. so that it does not require proof because the existence of the consequences arising from the offense is considered to have been perfect criminal acts. These formal provisions in the past are often used to ensnare statements in the form of criticism.

Furthermore, in article 16 of the UUITE requires the use of a perfectly safe electronic system, but it turns out that until now there are no specific rules or standards regarding the use of electronic systems. Besides that, there is still the emergence of moral hazard that exploits oversight weaknesses due to the existence of democracy and regional autonomy.

Likewise, the absence of clear standards relating to standards concerning violation of decency, the limits of actions included in the category of gambling, and interpretation of an act of humiliation. Furthermore, who will have the right to assess the standards of the deeds he or she has alleged.

Furthermore, in relation to legal jurisdiction there is also no perfect arrangement, for example if there is an Indonesian citizen who makes software specifically pornography abroad whether it is free from Indonesian law demands or how.

The above matters prove that the use of UUITE as a legal umbrella for regulating criminal acts in cyberspace is still experiencing many obstacles, therefore UUITE must be harmonized with the related criminal law because if it is different then it will cause legal imbalance so that it will 
further complicate enforcers law in enforcing the law.

\section{Conclusion}

1. Information technology products as electronic evidence are finally accepted as an extension (extensification) of the evidence provided for in article 188 paragraph 2 of the Criminal Procedure Code, with the enactment of UUITE, there are additional types of evidence. Besides that the electronic document is equal to the documents made on paper as specified in the general explanation of UUITE.

2. UU ITE specifically article 27 paragraph 1, 3, article 28 paragraph 2 and article 31 paragraph 3, these articles are considered to contain the rules of the rubber article (haatzai Pasalen), because they are flexible and highly dependent on user interpretation. In addition, there are no specifications or legal jurisdiction regarding the alleged offenses.

\section{BIBLIOGRAPHY}

\section{BOOK}

Andi Hamzah, Hukum Acara Pidana Indonesia, Sinar Grafika, Jakarta, 2009

Adnan Paslyadja, Hukum Pembuktian, Pusat Diklat kejaksaan Republik Indonesia, Jakarta, 1997

Dikdik M Arief dan Elisatris Gultom, Cyber law : Aspek Hukum Tehnologi Informasi, Refika Aditama, Bandung, 2009

Djoko Sarwoko, Pembuktian Perkara Pidana Setelah Berlakunya UU No 11 Tahun 2008 (Undang-Undang ITE), Tuada Pidana Khusus Mahkamah Agung

Hari Sasangka dan Lily Rosita, , Hukum Pembuktian Dalam Perkara Pidana, Mandar Maju, Bandung, 2003

Johan Wahyudi, Dokumen Elektronik Sebagai Alat Bukti Pada Pembuktian di Pengadilan, Jurnal: Perspektif Volume XVII No 2, Fakultas Hukum Universitas Airlangga ,Surabaya, Edisi Mei 2012

Minanoer Rachman, Penggunaan Informasi Sebagai alat Bukti Dalam Proses Litigasi, Bahan

Seminar, Fakultas Hukum Universitas Airlangga Surabaya, 16 Juni 2012

Subekti, Hukum Pembuktian, Pradya Paramita, Jakarta, 2001

\section{Website}

http://www.hukum online.com/berita: sudah banyak UU akui alat bukti elektronik, diakses pada tanggal 24 Oktober 2018 
http://www.arijuliano.blogspot.com/2008/04/07: apakah dokumen elektronik dapat menjadi alat bukti yang sah, diakses pada tanggal 8 November 2018

http://www.aguuuuung.blogspot.com/2013/06/16: Undang-undang ITE dan contoh kasusnya, diakses pada tanggal 24 Oktober 2018

http://warungcyber.web.id./?p=84:pengaturan alat bukti elektronik , diakses pada tanggal 24 oktober 2018

http://www.hukum online.com/klinik: syarat dan kekuatan alat bukti elektronik, diakses pada tanggal 8 November 2018

http://www.hukum online.com/berita: Perluasan alat bukti yang Sah dalam ITE, diakses pada tanggal 24 Oktober 2018

http://kampung9download.blogspot.com/2013/06/03 : Teori Pembuktian dalam Hukum Pidana, diakses pada tanggal 8 November 2018

http://thezmoonstar.blogspot.com/2013/07/08: sistim atau teori Pembuktian, diakses pada tanggal 8 November 2018 